\title{
Strategies adopted by Aphanizomenon flos-aquae in response to phosphorus deficiency and their role on growth
}

\author{
Xiaoyan Chen ${ }^{1,2}$, Iva Dolinova ${ }^{3}$, Alena Sevcu ${ }^{3}$, Tomasz Jurczakk ${ }^{4}$, Piotr Frankiewicz ${ }^{4}$, \\ Adrianna Wojtal-Frankiewicz ${ }^{4}$, Lingling Wan ${ }^{1,2}$, Qinghui Deng ${ }^{1,2}$, Chunlei Song ${ }^{1}$, Yiyong Zhou ${ }^{1}$ \\ and Xiuyun $\mathrm{CaO}^{1^{*}}$ (1)
}

\begin{abstract}
Background: The $\mathrm{N}_{2}$-fixing cyanobacterium, Aphanizomenon flos-aquae is a globally distributed bloom causing species that degrades water quality of fresh and marine water bodies. Overcoming phosphorus (P) deficiency is one of the ecological advantages for bloom-forming cyanobacteria. It remains unclear to what extent can A. flos-aquae alleviate $\mathrm{P}$ deficiency by regulating $\mathrm{P}$ using strategies.

Results: Based on in situ observations of extracellular alkaline phosphatase (APase) in A. flos-aquae via enzymelabeled fluorescence in freshwater bodies in China, Poland and Czechia, we further investigated responses of isolated A. flos-aquae to different $\mathrm{P}$ supplies (dissolved inorganic $\mathrm{P}$ (Pi) as +DIP, dissolved organic a-glycerophosphate and $\beta$-glycerophosphate as $+\mathrm{DOP}_{\alpha}$ and $+\mathrm{DOP}_{\beta}$, $\mathrm{P}$-free condition as $\mathrm{P}$-depleted). The significantly negative relationships between percentage of APase producing cells and soluble reactive $P$ concentration in both fields and cultures suggested that the excretion of APase in cyanobacterium was regulated by ambient Pi supply. Suffering from P deficiency in the P-depleted treatments, A. flos-aquae showed the highest APase activity but a vigorous growth at the early culture stage, which might also benefit from the formation of polyphosphate body (PPB) and the decrease of cell P quota. In the +DOP treatments, the coordination of dissolved DOP mineralization and continuous prompt utilization of PPB might contribute to a maintenance but not reproduction of $A$. flos-aquae when relying on DOP, since the specific growth rate kept around 0 cells $\mathrm{L}^{-1} \mathrm{day}^{-1}$ at the second half culture period and the highest cell density reached only $13.38 \%$ of that in +DIP treatments while photochemical efficiency was comparable during the whole experiment. Luxury uptake of phosphate as PPB in the +DIP treatments was consistent to the canonical view of polyphosphate as $P$ storage.
\end{abstract}

Conclusion: Aphanizomenon flos-aquae could achieve an instantaneous growth in response to $\mathrm{P}$ deficiency with the coordination of $\mathrm{P}$ utilization strategies, while it maintained a long-term sustainable growth but not reproduction under sole DOP supply. Persistent and active reproduction could only be achieved in high Pi supply, which implying that an effective consequence can be expected for combating the bloom of A. flos-aquae when controlling P supply.

Keywords: Aphanizomenon flos-aquae, P deficiency, Extracellular alkaline phosphatase, Polyphosphate body, Strategies for P utilization

*Correspondence: caoxy@ihb.ac.cn

1 Key Laboratory of Algal Biology, State Key Laboratory of Freshwater Ecology and Biotechnology, Institute of Hydrobiology, Chinese Academy of Sciences, 7\# Donghu South Road, Wuhan 430072, China Full list of author information is available at the end of the article

\section{Background}

Filamentous cyanobacterial blooms of the diazotrophic genus Aphanizomenon occur worldwide and pose deleterious effects on aquatic ecosystem [1-4]. Theoretically, 
the nitrogen demand of the developing population of Aphanizomenon can be provided by nitrogen fixation in heterocysts $[1,5,6]$. Thus, the phosphorus $(\mathrm{P})$ scarcity can most often lead to its growth limitation. For example, the first appearance of Aphanizomenon in Lake Kinneret in August 1994 was apparently elevated by relatively high total dissolved P concentrations [1]. Aphanizomenon behaved sensitively when exposed to changes in ambient dissolved inorganic $\mathrm{P}(\mathrm{Pi})$ so that it might be adapted to environments with higher $\mathrm{P}$ concentrations [7]. Orthophosphate in low concentrations led to a strong decrease in the growth of $A$. issatschenkoi, A. aphanizomenoides and A. gracile [8]. Correspondingly, bloomforming cyanobacteria developed various strategies to overcome P deficiency. A strategy for cyanobacteria to survive in $\mathrm{P}$ deficiency status was that they store $\mathrm{P}$ in the form of polyphosphate bodies (PPB) in cells when $\mathrm{P}$ is abundant, and breakdown it upon P stress [9]. Polyphosphate granules observed in cells of Aphanizomenon sp. from blooms in Baltic Sea suggested that the population was not subjected to P starvation [10]. Furthermore, Aphanizomenon had the ability to decrease cell $\mathrm{P}$ quota when $\mathrm{P}$ in their environment is scarce [7]. In addition, Aphanizomenon could meet its $\mathrm{P}$ demand by expressing extracellular alkaline phosphatase (APase), enzymes hydrolyzing bio-available phosphate from dissolved organic P (DOP) molecules [7, 11-13]. Like the Aphanizomenon in Lake Kinneret, whose biomass increased accompanying high enzymatic alkaline phosphatase activity (APA) in phosphate limited summer and autumn [1]. Aphanizomenon sp. which is one main bloom-forming filamentous diazotrophic species in Baltic Sea showed cell-surface-bound phosphatase activity as indicated by enzyme-labeled fluorescence (ELF) assays [13]. On the contrary, a combination of field and lab-cultures study showed that $A$. ovalisporum excreted APase only under severe P deficiency, it firstly enslaved another phytoplankton other than itself to produce APase [14]. In summary, APase production in the development of Aphanizomenon bloom at the single cell level in freshwater is rarely studied. Furthermore, it is still unclear to what extent can A. flos-aquae alleviate $\mathrm{P}$ deficiency by regulating $\mathrm{P}$ using strategies.

In this study, single-cell assays of APase were conducted at species level using the ELF technique in 2 Chinese lakes, 1 Czechia reservoir and 1 Polish reservoir. Furthermore, laboratory studies were performed with batch cultures, and three strains of Aphanizomenon flosaquae (A. flos-aquae FACHB 1249, A. flos-aquae FACHB 1171 and A. flos-aquae FACHB 1260) isolated from three Chinese shallow lakes such as Lake Chaohu, Lake Taihu and Lake Dianchi were inoculated in medium with four $\mathrm{P}$ status with additions of $\mathrm{Pi}$ and two DOP species, respectively, as well as without $\mathrm{P}$ addition. Multiple variables related to algal growth such as cell density and photosystem II quantum efficiency $(F v / F m)$, P cycling such as bulk and size-fractionation APA, concentrations of soluble reactive $\mathrm{P}(\mathrm{SRP})$ and DOP in culture medium, as well as the ELF labeling and PPB containing cells of the strains were determined at different intervals. Objectives of this study were (1) to investigate whether $A$. flos-aquae could employ its own APase in acquiring P from DOP for cell growth and reproduction, and (2) to evaluate to what extent can $A$. flos-aquae abate the P limitation with various $\mathrm{P}$ using strategies.

\section{Materials and methods}

\section{Field sample collection and analysis}

Field samples of surface water $(0-50 \mathrm{~cm})$ from Lake Chaohu, Lake Zhiyin (China), Reservoir Orlík (Czechia) and Reservoir Stefanski (Poland) were collected for chemical, biological and biochemical analysis on 05th Jun. 2018, 18th Jan. 2018, 22nd Oct. 2014 and 26th Aug. 2010, respectively (Additional file 1: Fig. S1, Table S2). 2 $\mathrm{L}$ of samples were taken and transported to the laboratory immediately. Fresh phytoplankton samples were inspected to minimize difficulties in determining species on the membrane filters. SRP concentrations were determined according to Murphy and Riley [15] after filtering with cellulose acetate membrane $(0.45 \mu \mathrm{m}$ pore diameter size). ELF method was used to quality detect APase on single-cell level. Samples obtained from field were treated using ELF $^{\circledR} 97$ phosphate (ELFP, Invitrogen ${ }^{\mathrm{TM}}$ ) on the basis of the protocol described in Strojsova et al. [11]. $0.5 \mathrm{~mL}$ incubations were started by adding the ELFP solution (final concentration $27 \mu \mathrm{M}$ ) and samples were incubated at $25^{\circ} \mathrm{C}$ for $2.5 \mathrm{~h}$. Each incubation was terminated by transferring the sample to a filter holder (diameter $7 \mathrm{~mm}$ ) with a membrane filter (Millipore; $0.22 \mu \mathrm{m}$ pore size). The filter with retained algae were placed on a microscope slide, embedded it with the anti-fading reagent Citifluor AF1 (Citifluor, London, UK), and covered with a cover slide for microscopic inspection. ELF-labeling cells were inspected by epifluorescence microscopy (Olympus BX51FL). 20-50 (depending on the cell density) images were taken randomly on the filters. The active and inactive cells with fluorescence were recorded in each image to quantify the percentages of cells with ELF labeling.

\section{Experiment design in laboratory culture}

Three strains of $A$. flos-aquae FACHB 1249 (A. flosaquae 1249 for short), A. flos-aquae FACHB1171 (A. flos-aquae 1171 for short) and A. flos-aquae FACHB 1260 (A. flos-aquae 1260 for short) were attained from Freshwater Algae Culture Collection of Institute of Hydrobiology (Wuhan, China). Prior to experiments, cells 
were harvested in the exponential growth period by centrifugation $(3000 \mathrm{rpm}, 10 \mathrm{~min})$, rinsed 3 times with P-free BG11 medium and then cultivated in P-free BG11 medium for $48 \mathrm{~h}$ to consume $\mathrm{P}$ stored in cells to a low level and equal basis [16]. After that, the culture was inoculated in BG11 [17] medium with modified P concentrations and the modifying sets were as follows:

A culture using $\mathrm{K}_{2} \mathrm{HPO}_{4}$ as the sole $\mathrm{P}$ source was defined as +DIP treatment. In P-depleted treatment, $\mathrm{K}_{2} \mathrm{HPO}_{4}$ was replaced by $\mathrm{KCl}$. $\alpha$-glycerophosphate and $\beta$-glycerophosphate alternated $\mathrm{K}_{2} \mathrm{HPO}_{4}$ with the same amount of $\mathrm{P}$ in the treatments of $+\mathrm{DOP}_{\alpha}$ and $+\mathrm{DOP}_{\beta}$. We conducted the experiments in sterile condition to avoid exotic bacterial contamination.

Initial cell density of $A$. flos-aquae in each culture was roughly $5 \times 10^{8}$ cells $\mathrm{L}^{-1}$. All cultures were incubated in conditions suitable for cyanobacterial growth: constant white light intensity of $30 \mu \mathrm{mol}$ photons $\mathrm{m}^{-2} \mathrm{~s}^{-1}$ irradiance, $12 \mathrm{~h}$ of light: $12 \mathrm{~h}$ of dark, and $25^{\circ} \mathrm{C}$.

Subsamples were collected at different intervals over 59 days for chemical and biochemical analysis, e.g., SRP and DOP concentrations, cell density, photochemical efficiency, cell $\mathrm{P}$ quota, quality and quantity determination of APase, $\mathrm{P}$ storage detection, etc.

\section{Cell density, specific growth rate and photochemical efficiency of photosystem II}

Samples for cell density estimation were preserved with Lugol's solution and counted with an Olympus BX 41 microscope (Olympus Corporation, Japan) [18]. The specific growth rate was calculated according to the following equation: $\mu=(\ln \mathrm{Ct} 2-\ln \mathrm{Ct} 1) /(\mathrm{t} 1-\mathrm{t} 0)$, where $\mathrm{Ct} 2$ and $\mathrm{Ct} 1$ are cell densities at times $\mathrm{t} 2$ and $\mathrm{t} 1$, respectively [19].

$\mathrm{Fv} / \mathrm{Fm}$ is one of the chlorophyll fluorescence parameters which could reflect the maximum quantum yield of the photochemistry. The value of $F v / F m$ will decrease when plant was stressed by environmental conditions so that it is often used to evaluate whether the plant is subjected to conditional inhibition [20]. It was examined by Water PAM2100 (Walz, Germany) and determined according to Ting and Owens [21].

\section{$P$ concentrations and cell $P$ quota}

SRP concentration was determined using the same method as field investigation. Total phosphorus (TP) and total dissolved phosphorus (DTP) concentrations were measured following digestion according to the measurement reported by Beattie et al. [22]. DOP concentration was calculated as the difference between DTP and SRP concentrations.

Aliquots of $5 \mathrm{~mL}$ from individual cultures were harvested onto $25 \mathrm{~mm} \mathrm{GF/F}$ glass fiber filters (Waterman,
UK) for the measurement of TP in samples to determine the specific total P content of cells according to Vahtera et al. [12].

\section{Size-fractionation of APA}

APA was quantified by fluorometric assay [23]. It was determined in unfiltered sample $\left(\mathrm{APA}_{\mathrm{T}}\right)$ and the filtrates through $3.0 \mu \mathrm{m}$ and $0.45 \mu \mathrm{m}$ membrane filters $\left(\mathrm{APA}_{<3.0 \mu \mathrm{m}}\right.$ and $\mathrm{APA}_{<0.45 \mu \mathrm{m}}$, respectively). $150 \mu \mathrm{L}$ of Tris- $\mathrm{HCl}(\mathrm{pH}=8.5)$ was added to $2.7 \mathrm{~mL}$ subsample, after pipetting aliquots of fluorogenic substrate (MUFP-phosphate, final concentration of $100 \mu \mathrm{M}$ ), fluorescence was measured immediately, after incubation at room temperature for $2 \mathrm{~h}$, fluorescence was read again. The contribution of APA to the algal $\left(\mathrm{APA}_{>3.0 \mu \mathrm{m}}\right)$ and bacterial $\left(\mathrm{APA}_{0.45-3.0 \mu \mathrm{m}}\right)$ fractions were calculated as follows: $\mathrm{APA}_{>3.0 \mu \mathrm{m}}=\mathrm{APA}_{\mathrm{T}}-\mathrm{APA}_{<3.0 \mu \mathrm{m}}$, $\mathrm{APA}_{0.45-3.0 \mu \mathrm{m}}=\mathrm{APA}_{<3.0 \mu \mathrm{m}}-\mathrm{APA}_{<0.45 \mu \mathrm{m}}$, in which $\mathrm{APA}_{<0.45 \mu \mathrm{m}}$ represented the dissolved phosphatase activity [24].

\section{Fluorescence measurements and microscopic inspections}

In addition to determining the quality of algal APase by ELF method, we detected PPB in cultures of $A$. flos-aquae by DAPI (4',6-diamidino-2-phenylindole) according to the procedure of Bar-Yosef et al. [14]. $0.5 \mathrm{~mL}$ incubations were started by adding the DAPI solution (final concentration $15 \mu \mathrm{M}$ ) and samples were incubated at room temperature in dark for 5 min to detect PPB accumulation. Incubation termination, slide embedded protocol and inspection were the same as the stain of ELF. DAPI could bind to polyphosphate and show a yellow fluorescence at $526 \mathrm{~nm}$ under UV excitation $[25,26]$.

\section{Statistical analysis}

Pearson's correlation analysis and linear regression were carried out to analyze the relationships between SRP concentration and ELFp, APA and ELFp. The significant differences among four treatments were determined by ANOVA analysis and the differences were considered significant at $P<0.05$ or $P<0.01$. SPSS statistical software (version 18.0, Chicago, IL, USA) was used for those analyses. Data were log transformed to fit normal distribution. The plots of regression were drawn by SigmaPlot 10.0 .

\section{Results}

Differences in growth of $A$. flos-aquae in various $P$ supply

The three A. flos-aquae strains of the four treatments yielded similar cell density increasing from around $5.0 \times 10^{8}$ cells $\mathrm{L}^{-1}$ to $1.5 \times 10^{9}$ cells $\mathrm{L}^{-1}$ at first 8 days (Fig. 1). The cells in the P-depleted and +DIP treatments were then rapidly growing until the day 20 as indicated 


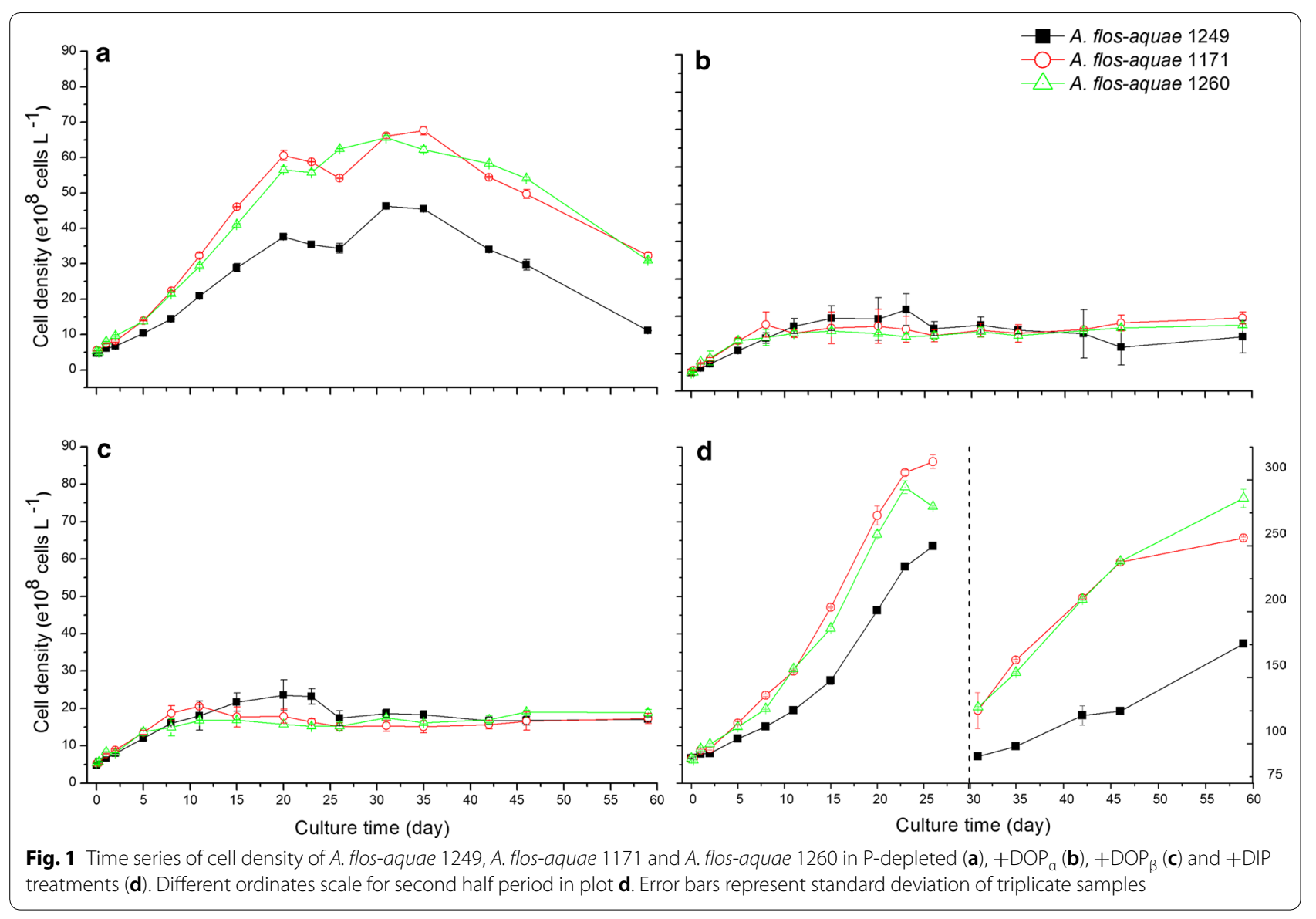

by the gradually increasing of cell densities and positive specific growth rates (Figs. 1a, d, 2a, d). Moreover, the specific growth rates in the P-depleted treatments had the highest values among all the treatments in the first 20 days (Fig. 2a). After that, specific growth rates fluctuated negatively and positively leading the peak cell densities at day $31\left(4.6,6.6\right.$ and $6.5 \times 10^{9}$ cells $\mathrm{L}^{-1}$ in $A$. flos-aquae 1249, A. flos-aquae 1171 and $A$. flos-aquae 1260, respectively), followed by specific negative growth rates (Fig. 2a) together with remarkable drop in cell densities (Fig. 1a) till the end of the experiment. On the contrary, the growth rates kept constantly positive in the +DIP treatments (Fig. 2d). As a result, the highest cell densities were observed at the end of the experiment (1.75, 2.55 and $2.86 \times 10^{10}$ cells L $^{-1}$ in A. flos-aquae 1249 , A. flos-aquae 1171 and A. flos-aquae 1260, respectively) (Fig. 1).

The specific growth rates in the $+\mathrm{DOP}_{\alpha}$ and $+\mathrm{DOP}_{\beta}$ treatments were the lowest compared with other two treatments in the first 20 days, after then they fluctuated around zero till the end of the experiment (Fig. 2b, c). Furthermore, the specific growth rates in the +DOP treatments were significantly lower than that of +DIP

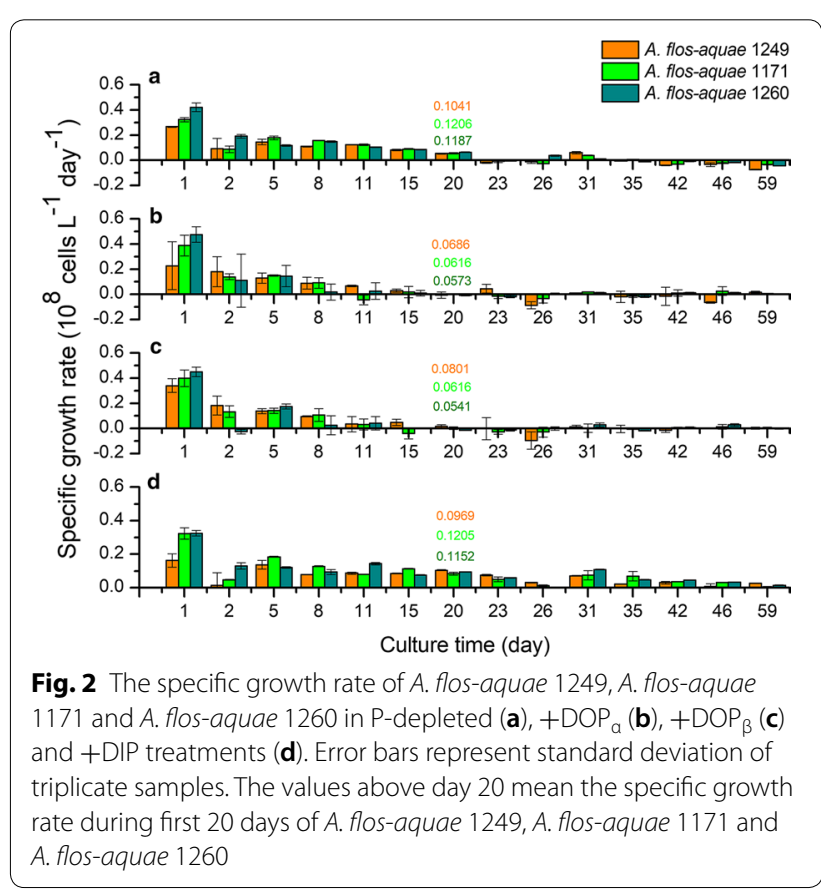


treatment among three culture strains $(P<0.05)$. In terms of cell density, DOP treatments gave comparable value firstly. After day 8 , the lowest cell density was observed in the DOP treatments spatially. In details, the maximum cell density in the $+\mathrm{DOP}_{\alpha}$ and $+\mathrm{DOP}_{\beta}$ treatments was $2.3 \times 10^{9}$ cells $\mathrm{L}^{-1}$ for the three strains, reaching only $47.16 \%$ and $50.82 \%$ for $A$. flos-aquae $1249,28.94 \%$ and $30.43 \%$ for $A$. flos-aquae $1171,26.84 \%$ and $29.02 \%$ for $A$. flos-aquae 1260 of that in P-depleted treatments, respectively. When compared with + DIP treatments, the maximum cell densities in the $+\mathrm{DOP}_{\alpha}$ and $+\mathrm{DOP}_{\beta}$ treatments were $12.42 \%$ and $13.38 \%$ for $A$. flos-aquae $1249,7.64 \%$ and $8.04 \%$ for A. flos-aquae $1171,6.1 \%$ and $6.66 \%$ for A. flos-aquae 1260 of that, respectively. Noticeably, the cell densities in the $+\mathrm{DOP}_{\alpha}$ and $+\mathrm{DOP}_{\beta}$ kept increased before day 11 , then they stabilized ranging from $1.5 \times 10^{9}$ cells $\mathrm{L}^{-1}$ to $2.0 \times 10^{9}$ cells $\mathrm{mL}^{-1}$ (Fig. $1 \mathrm{~b}, \mathrm{c}$ ).

\section{Photochemical efficiency of photosystem II in different treatments}

The photochemical efficiency of photosystem II ( $F v /$ $F m$ ) values remained relatively consistent at 0.400 to 0.538 during the whole incubation period in the +DIP treatments (Fig. $3 \mathrm{~d}$ ). So did the $F v / F m$ values in the $+\mathrm{DOP}_{\alpha}$ and $+\mathrm{DOP}_{\beta}$ treatments fluctuating from 0.251 to 0.590 (Fig. 3b, c). In the P-depleted treatments, $F v /$ $F m$ values were comparable with that in the +DIP treatments before day 31 , while it dropped sharply at the end of the experiment $(0.014,0.077$ and 0.037 for $A$. flos-aquae 1249, A. flos-aquae 1171 and $A$. flos-aquae 1260, respectively; Fig. 3a).

\section{SRP and DOP concentrations in different treatments}

SRP concentrations were determined in all treatments while DOP concentrations were determined only in $+\mathrm{DOP}_{\alpha}$ and $+\mathrm{DOP}_{\beta}$ treatments. The P-depleted treatments always showed the lowest SRP concentrations among the treatments (Fig. 4a). In the $+\mathrm{DOP}_{\alpha}$ and $+\mathrm{DOP}_{\beta}$ treatments, the SRP concentrations rapidly peaked the value of around $3500 \mu \mathrm{g} \mathrm{L}^{-1}$ at the first 15 days with the DOP concentrations decreasing to almost $0 \mu \mathrm{g} \mathrm{L}^{-1}$. The SRP concentrations stabilized around 2700 to $3000 \mu \mathrm{g} \mathrm{L}^{-1}$ after then (Fig. 4b, c). In the +DIP treatments, the SRP concentrations declined gradually until day 20 and more rapidly thereafter. Moreover, they decreased under the levels of detection limit at day 46 in the strains of A. flos-aquae 1171 and A. flos-aquae 1260 (Fig. 4d).

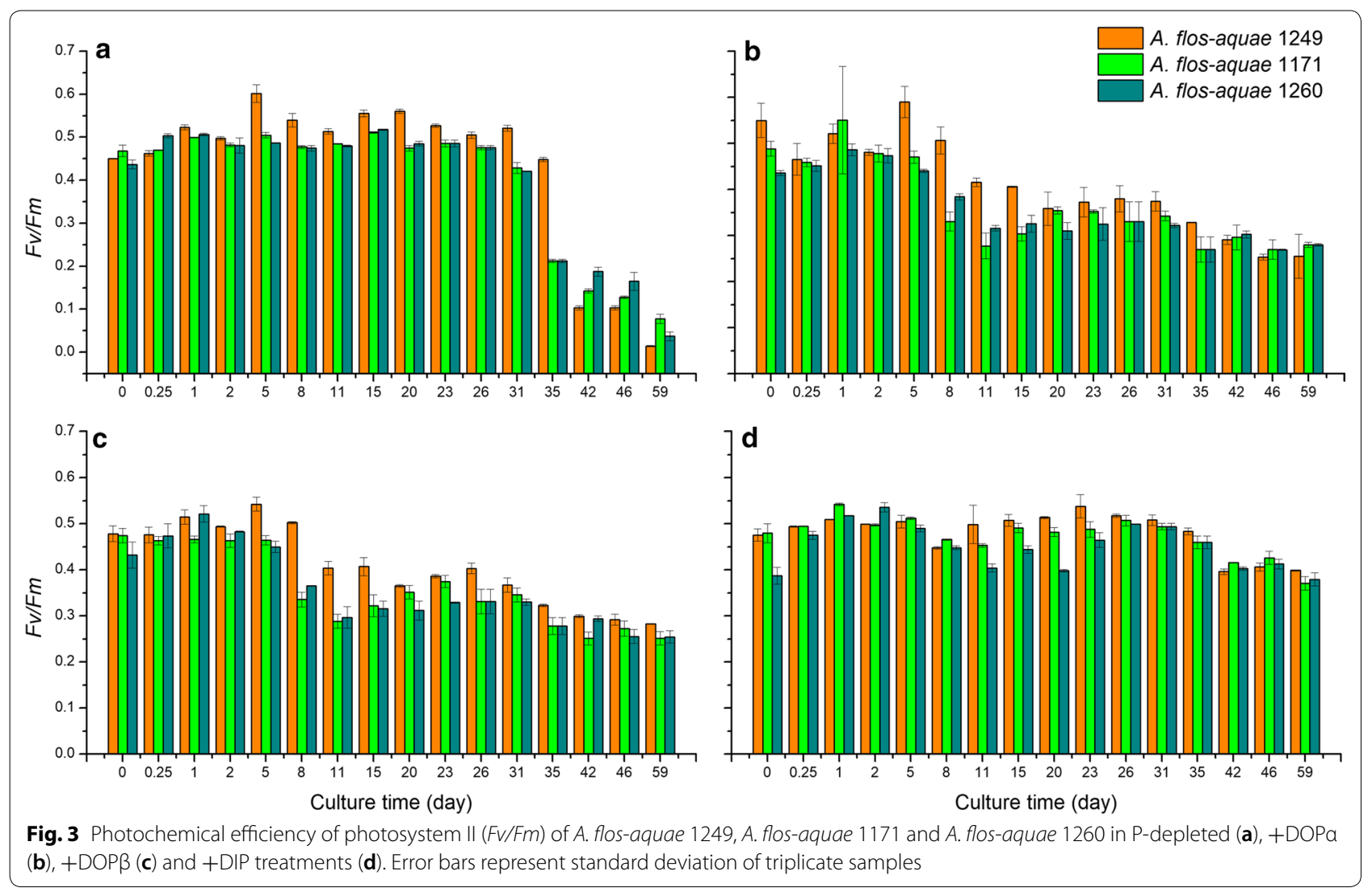



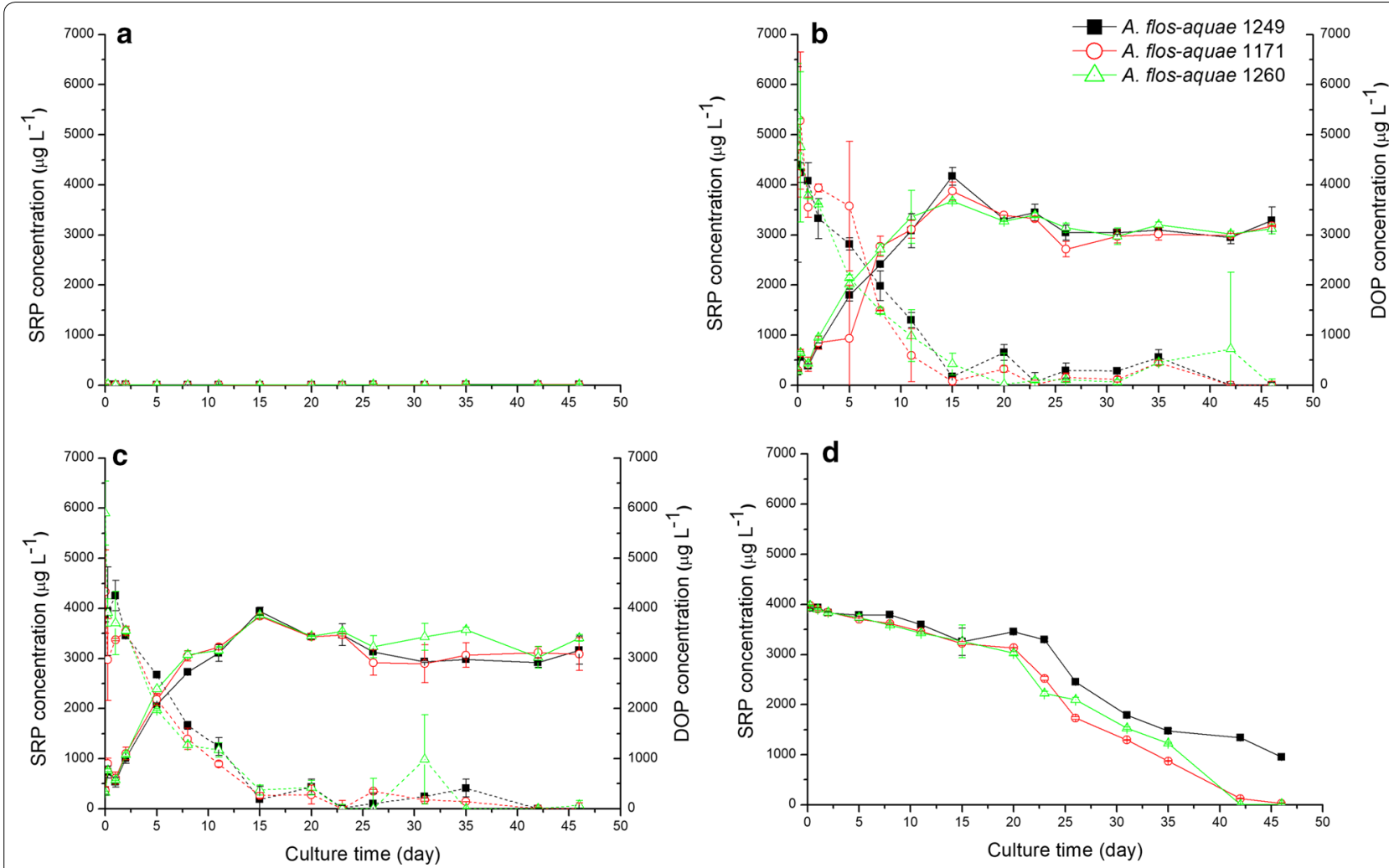

Fig. 4 The P concentrations of A. flos-aquae 1249, A. flos-aquae 1171 and A. flos-aquae 1260 in P-depleted (a), $+D_{0} P_{\alpha}(\mathbf{b}),+D O P_{\beta}(\mathbf{c})$ and +DIP treatments (d). The full and dash lines represent SRP and DOP concentrations, respectively, the solid square, circle and triangle represent the strains of A. flos-aquae 1249, 1171 and 1260, respectively. Error bars represent standard deviation of triplicate samples

\section{Expression of APase and its relationship with ambient $P$}

The active ELF signals, indicating extracellular APase expression, in cells of $A$. flos-aquae were observed in the samples from different subtropical and temperate water bodies in Czechia, Poland and China, as well as in the studied strains (Fig. 5). Noticeably, the ambient SRP concentration was $681 \mu \mathrm{g} \mathrm{L} \mathrm{L}^{-1}$ in Reservoir Stefanski in Poland, which was 13-49 times higher than that in the other three field samples (Additional file 1: Table S1). In addition, the ELFp of $A$. flos-aquae was negatively related to the SRP concentration in Lake Chaohu $(r=-0.1159$, $P<0.05$, Fig. 6a). The two parameters also correlated negatively in the cultures among four treatments in the lab-culture $(r=-0.2590,-0.2391$ and -0.1694 for $A$. flos-aquae 1249, 1171 and 1260, respectively; $P<0.01$, Fig. 6b).

In the cultures, the ELFp exhibited significantly positive relationship with $\mathrm{APA}_{>3.0 \mu \mathrm{m}}$ for all strains $(r=0.8145$, $0.7118,0.834$ for P-depleted, $+\mathrm{DOP}_{\alpha}$ and $+\mathrm{DOP}_{\beta}$ treatments, respectively; $P<0.01$ ) (Additional file 1: Fig. S2), and the $\mathrm{APA}_{>3.0 \mu \mathrm{m}}$ accounted for the largest part of $\mathrm{APA}_{\mathrm{T}}$ (round to 50-70\%) for each treatment (Additional file 1: Fig. S3). In the P-depleted treatments, $\mathrm{APA}_{>3.0 \mu \mathrm{m}}$ together with the percentages of cells with ELF labeling (ELFp) were significantly higher than those in the other treatments for all strains $(P<0.01)$ (Additional file 1: Figs. S3, S4). In addition, the ELFp in $+\mathrm{DOP}_{\alpha}$ and $+\mathrm{DOP}_{\beta}$ treatments were significantly lower than that in the P-depleted treatments $(6.6$ to $9.5 \%$ of that in the P-depleted treatments; $P<0.01)$ while they were significantly higher than that in +DIP treatments (17.8- to 25.6-fold of that in the + DIP treatments; $P<0.01$ ) (Additional file 1: Fig. S4).

\section{Cell P quota and PPB containing cells in different culture treatments}

The cell P quota in the P-depleted treatments showed significant lower values compared to that in the other ones $(P<0.01)$ (Fig. 7$)$. The PPB were observed in each culture, with the initial percentages of $\mathrm{PPB}$ containing cells (PPBp) being around $0.05 \%$. PPBp in the $\mathrm{P}$-depleted treatments was significantly lower than that in the other treatments $(P<0.01)$ (Fig. 8). Noticeably, PPB containing cells could be observed at first day 15 (Fig. 8a). PPBp began to increase at first (for A. flosaquae 1171, 1260) or second (for A. flos-aquae 1249) day and peaked at day 5 . It rapidly declined to 0 at day 

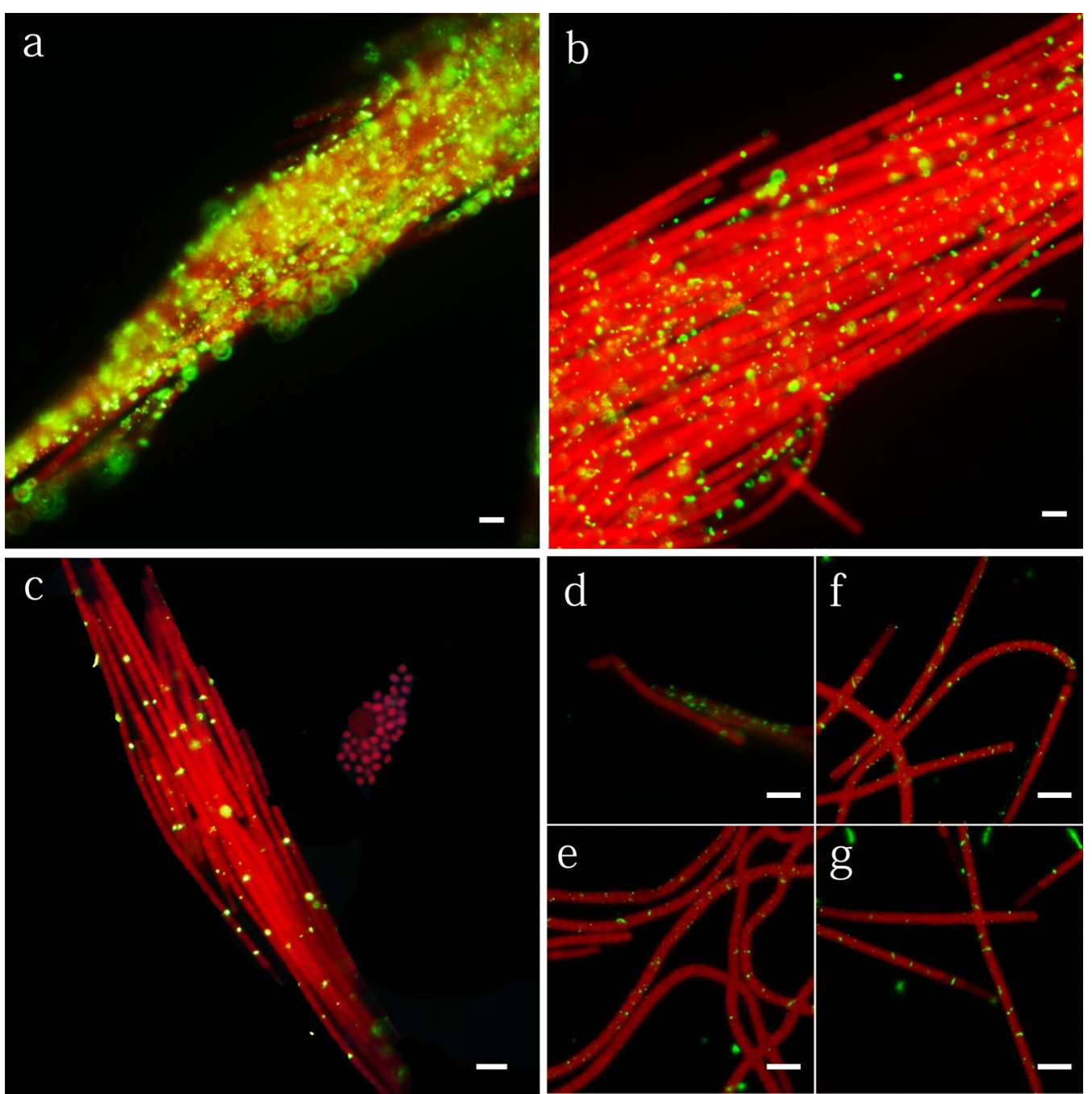

Fig. 5 Aphanizomenon flos-aquae treated with ELF reagent for extracellular alkaline phosphatase (APase) detection. Green ELF fluorescence associated with A. flos-aquae obtained from Reservoir Orlík in Czechia (a) and Reservoir Stefanski in Poland (b), shallow lakes of Lake Chaohu (c) and Lake Zhiyin (d), as well as the culture strains of A. flos-aquae 1249 (e), A. flos-aquae 1171 (f) and A. flos-aquae 1260 (g). Scale bars indicate $10 \mu \mathrm{m}$

15 in A. flos-aquae 1171 and 1260 . Though demonstrating the same pattern, PPBp in A. flos-aquae 1249 was obviously lower than that in the other two strains. In the +DIP treatments, PPBp increased from day 1 and reached maximum at day 2 , and remaining constant (85-93\%) until day 42. In terms of strains, the PPBp decreased in A. flos-aquae 1171 and A. flos-aquae 1260 at day 46 to $74 \%$ and $78 \%$, respectively (Fig. $8 d$ ). In the $+\mathrm{DOP}_{\alpha}$ and $+\mathrm{DOP}_{\beta}$ treatments, the PPBp fluctuated regularly with incubation time. In details, the PPBp reached a level (over 80\%) comparable to that in the +DIP treatments at first days and decreased to $10-40 \%$ several days later and went up and down later on (Fig. 8b, c). Furthermore, PPB numbers per cell varied greatly among the different cultures (Fig. 9). It was rich and constant in the + DIP treatments (Fig. 9e and f) while fluctuated in $+\mathrm{DOP}_{\alpha}$ and $+\mathrm{DOP}_{\beta}$ treatments (Fig. 9a-d).

\section{Discussion}

Whether cyanobacteria alleviated P deficiency by producing APase is rarely studied, despite numerous studies having showed that it did so in phytoplankton in freshwater and ocean by evaluating the APA in situ and cultures [27-32]. The current study illustrated the P utilization adoption of A. flos-aquae in response to various $\mathrm{P}$ supply and its role in regulating the growth and reproduction. A vigorous growth at the early stage in the P-depleted treatment might be owing to the cooperation 

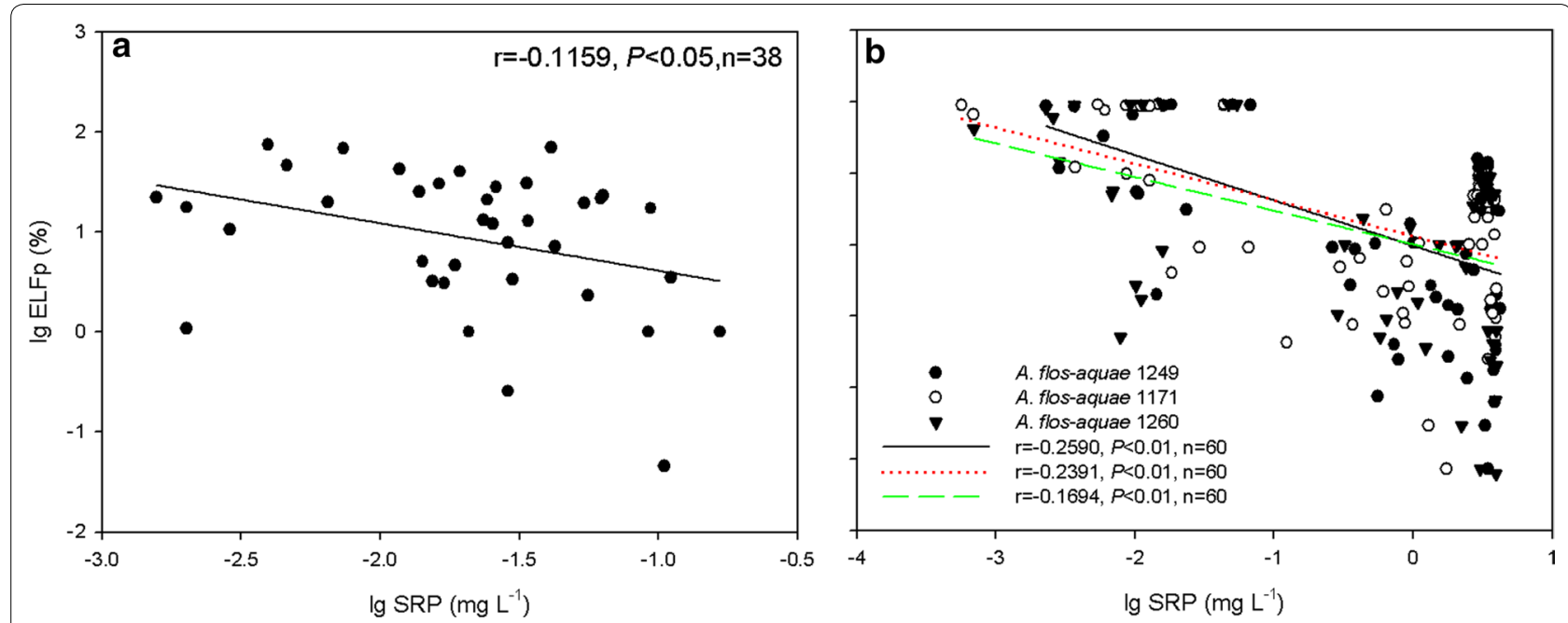

Fig. 6 Relationships between the percentages of cells with ELF labeling (ELFP) in A. flos-aquae and the SRP concentrations in Lake Chaohu (a) and in lab-culture (b)
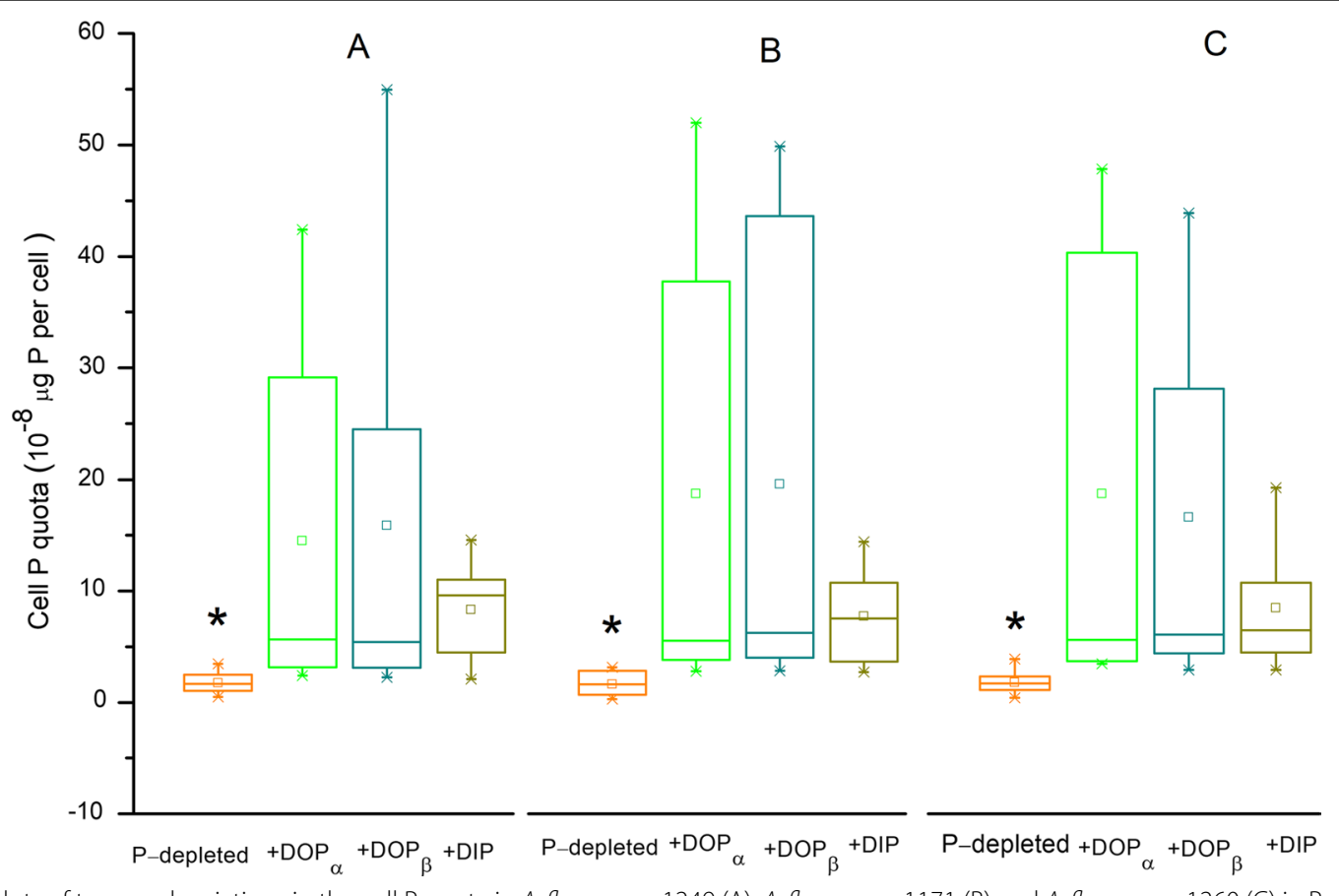

Fig. 7 Box plots of temporal variations in the cell P quota in A. flos-aquae 1249 (A), A. flos-aquae 1171 (B) and A. flos-aquae 1260 (C) in P-depleted, $+\mathrm{DOP}_{\alpha^{\prime}}+\mathrm{DOP}_{\beta}$ and $+\mathrm{DIP}$ treatments. The $\times$ from the two sides of the column are the minimum and maximum of ELFp, the full lines represent $25 \%$ percentiles of the variables, median values and $75 \%$ percentiles of the variables. The small squares within the column are their averages. Asterisks $(*)$ indicate significant difference $(P<0.01)$ among treatments

of P utilization strategies in A. flos-aquae, e.g., producing APase, increase PPB formation and decrease cell $\mathrm{P}$ quota. Unexpectedly, A. flos-aquae in the treatment of DOP gave the cell density reaching around $13 \%$ of that in replete Pi control, even though the quantity and quality of APase were observed and the substrate monoester was sufficient. No growth rate could be determined, while the photochemical efficiency was comparable to the treatment of + DIP, indicating that A. flos-aquae maintained its metabolic activity by enzymatic hydrolyzing $\mathrm{P}$ but not reproduced when DOP was supplied as a sole source of $P$. 


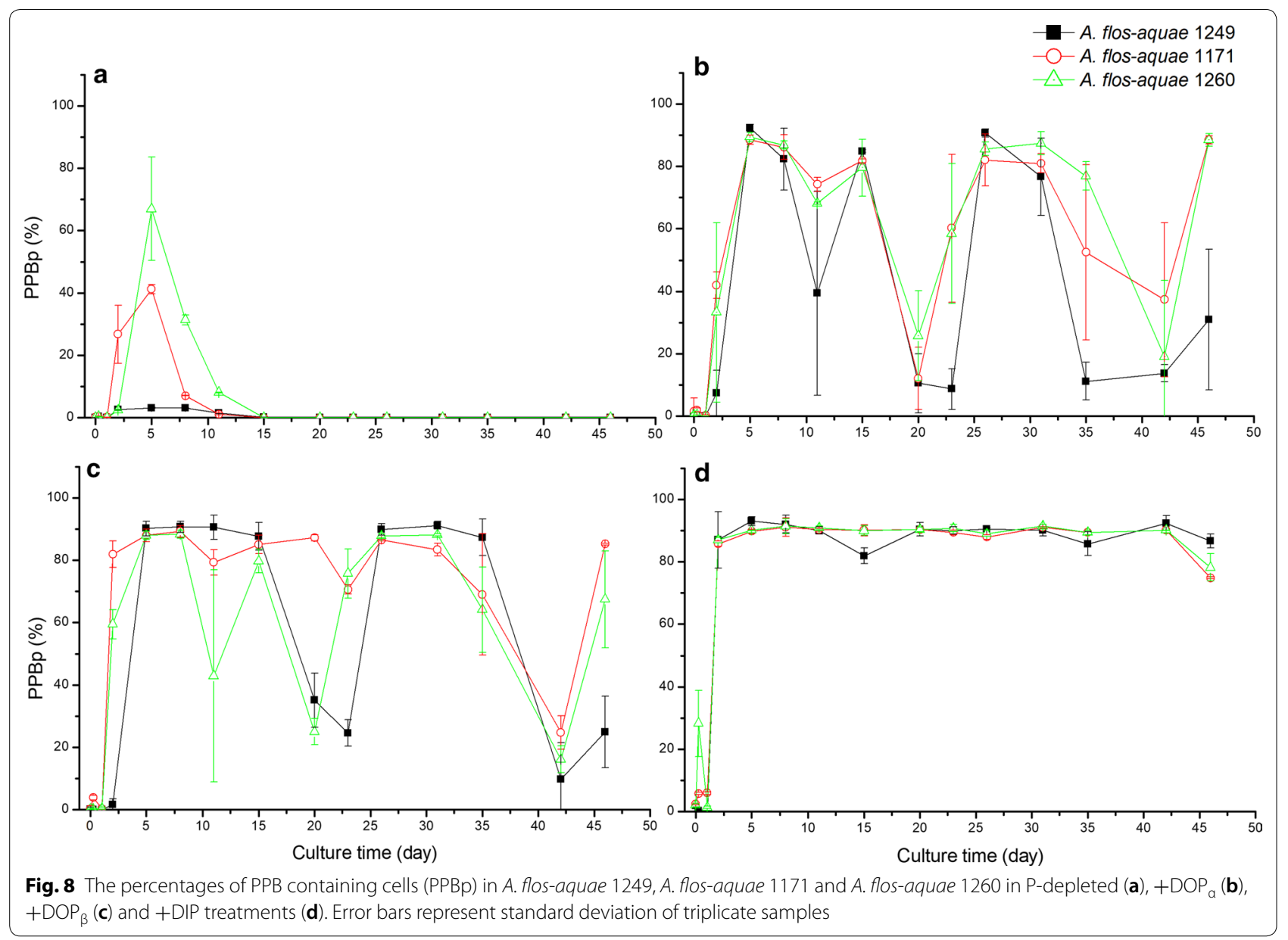

The ELF signals in cells of A. flos-aquae in the field and lab-culture and the inverse relationship between the percentage of active cells (or the APA contributed by algal cells) and the SRP concentration indicated that the APase excretion by $A$. flos-aquae was regulated by the ambient $\mathrm{P}$ concentration, which was commonly observed so that high APA was recommended as an indicator of P stress or limitation $[28,33,34]$. It is reasonable that A. flosaquae produced APase in Lake Chaohu, Zhiyin and Reservoir Orlík where the SRP concentration varied between 14 and $51 \mu \mathrm{g} \mathrm{L}^{-1}$. Unexpectedly, it still produced APase where SRP concentration was 13-49 times higher in Reservoir Stefanski in Poland (Additional file 1: Table S1). A possible explanation for these observations might be that the threshold for APase initiation may be strain-specific so as to response to local environmental conditions. Phytoplankton species would respond to P deficiency at various concentrations of SRP. For example, Prorocentrum minimum began to express APA at a higher SRP concentration than Chaetoceros neogracile, Chlorella autotrophica, Isochrysis sp. and Tetraselmis chui did using the ELF method [35]. In addition, a repression of the synthesis of
APase was observed over an orthophosphate concentration threshold between 0.4 and $1 \mu \mathrm{M}$ in Alexandrium catenella in the France lagoon [36]. In time-course experiment, the APA was induced at orthophosphate concentration at $0.43 \mathrm{mM}$ for Alexandrium tamarense isolated from Hiroshima Bay [37]. These results indicated that the threshold for producing APase is species specific, while our field and culture observations indicated that it might be strain-specific among A. flos-aquae. On the other hand, scientists also referred to APA's contribution to phytoplankton $\mathrm{P}$ absorption and growth in mineralizing DOP $[31,38]$. It was quantified that up to $89 \%$ of the total phytoplankton $\mathrm{P}$ uptake was represented by APA in Lake Wivenhoe of Australia [39]. In addition to algae, free living and attached bacteria were the main contributors to APA [40-42]. In our experiments, $\mathrm{APA}_{>3.0 \mu \mathrm{m}}$ accounted for the most part of $\mathrm{APA}_{\mathrm{T}}$ (see Additional file 1: Fig. S3). We could not exclude the contribution of the attached bacteria to $\mathrm{APA}_{>3.0 \mu \mathrm{m}}$. But the positive relationship between ELFp and APA $>3.0 \mu \mathrm{m}$ (see Additional file 1: Fig. S2) indicated that an anomaly thriving growth of A. flos-aquae in the P-depleted treatments at the first 

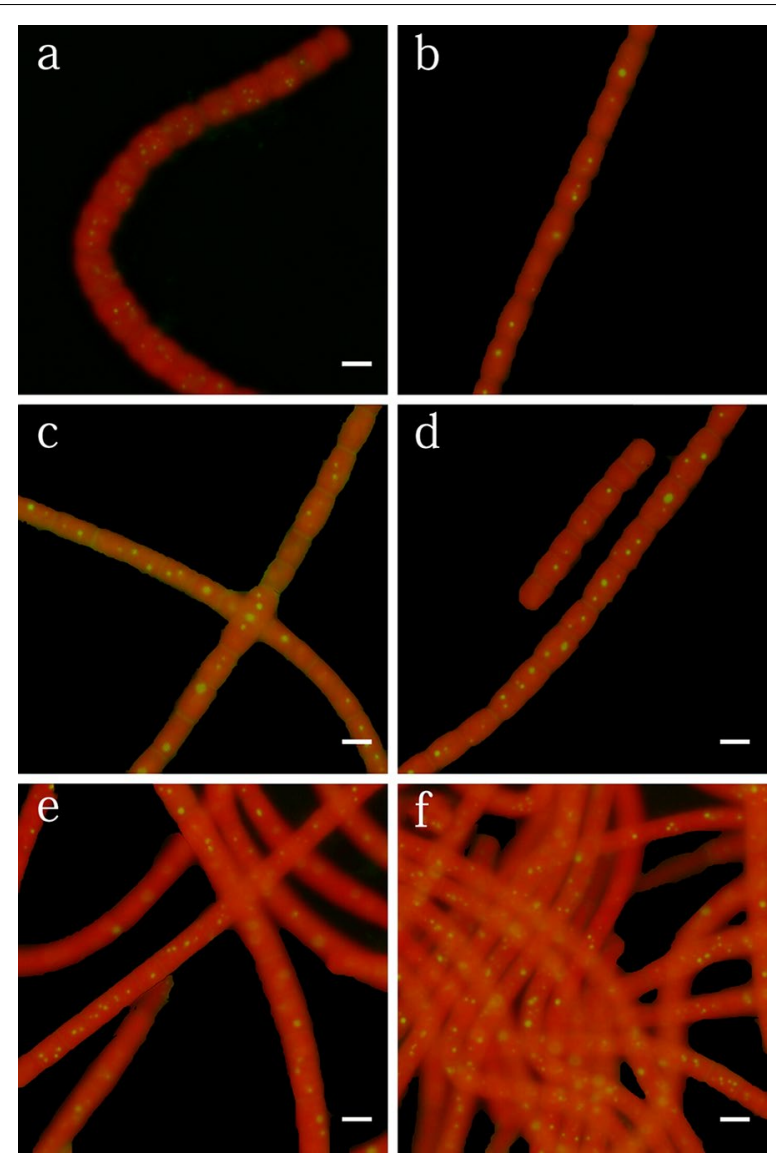

Fig. 9 Polyphosphate body (PPB) detection in A. flos-aquae in fluorescence microscope (only shown the images of $A$. flos-aquae 1171). Chlorophyll fluorescence is red and green-yellow fluorescence marks DAPI-stained PPB. Number of PPB within cells varied in the $+\mathrm{DOP}_{\alpha}(\mathbf{a}, \mathbf{b})$, and $+\mathrm{DOP}_{\beta}$ treatments $(\mathbf{c}, \mathbf{d})$, it maintained constant in the + DIP treatment $(\mathbf{e}, \mathbf{f})$. Scale bars indicate $10 \mu \mathrm{m}$

31 days might attribute to the DOP mineralization by APase secreted by A. flos-aquae. The origin of the DOP might be released from the algal cells. For example, DOP was excreted when phosphate concentrations were less than the sensitivity of the molybdate test for orthophosphate in freshwater algae of Chlorella, Scenedesmus, Navicula and Anabaena [43]. Therefore, the new formation of PPB in P-depleted treatments was probably from the hydrolysis of DOP released from A. flos-aquae as evidenced by the fluctuation of PPBp (Fig. 8a). This pattern of PPB forming was contradicted to the canonical point of polyphosphate as a luxury $\mathrm{P}$ storage molecule. In accordance with our study, polyphosphate accumulation was observed in cells of $A$. flos-aquae obtained from a summer bloom in the central Baltic Sea, where only small amounts of phosphate were available in the ambient environment, which could help to compete with other microorganisms for phosphate during bloom [44]. In addition, the phytoplankton in the western North Atlantic was enriched in polyphosphate in the P-depleted subtropical Sargasso Sea compared with nutrient-replete temperate waters, proposing that the polyphosphate cycle might produce a feedback loop, which reduces the $\mathrm{P}$ export when it is lacking and makes contribution to bio-available $\mathrm{P}$ for primary production [45]. Another explanation for this transitory growth is that A. flosaquae decreased the requirement of cellular $\mathrm{P}$ and alleviated P deficiency to some extent. The lowest cell P quota was found in this treatment (Fig. 7). Consistently, the N:P ratios and intracellular P demand in A. flos-aquae TR183, Nodularia spumigena AV1 and Trichodesmium erythraeum IMS101 can be remarkably plastic in response to P deficiency [12, 46]. It was, therefore, inferred that the A. flos-aquae utilized some strategies such as the promotion of excreting APase, elevation of PPB formation and reduction of $\mathrm{P}$ demand to gain maximum growth at the circumstance of $\mathrm{P}$ deprivation. This hypothesis was verified by the field observation in Lake Chaohu that high percentage of ELF labeling was accompanied by high biomass. Our previous work about another $\mathrm{N}_{2}$-fixing genus Dolichospermum flos-aquae also suggested that it suffered from severe P limitation at the end of the bloom [24]. An obviously lower cell P quota was observed in cyanobacteria during their bloom (unpublished data) and its underlying mechanism needs further investigation.

Unlike the pattern of PPB forming in the P-depleted treatments, it seemed following the classical view as a luxury $\mathrm{P}$ storage molecule in the + DIP treatments. The types of PPB may explain this variation. Polyphosphate can be classified as acid-soluble polyphosphate (ASP) and acid-insoluble polyphosphate (AISP). ASP is considered to be used for metabolism and production of DNA and protein, it can also act as a function of shortterm P pool. In contrast, AISP appears to be a form of $P$ storage that could be utilized by the cell for growth when the P concentration is limiting in external environment $[47,48]$, which enables cell divisions in the absence of any exogenous phosphate $[49,50]$. Additionally, this polyphosphate was only utilized by microalgae when phosphate concentration of the waste-water reached a growth limiting level [48]. The three strains of A. flos-aquae in the +DIP treatments remained active growth after the lag phase and gave the highest cell density with the PPBp as well as number of PPB per cell in constant levels (Figs. 8d, 9e, f). A. flos-aquae appeared to use the storage $\mathrm{P}$ to achieve active growth in relation to the positive growth rate after day 46 when the SRP concentrations were decreased into the levels of that in the P-depleted treatments in the strains A. flos-aquae 1171 and A. flos-aquae 1260, where the 
PPBp declined then (Fig. 8d). The main component of the PPB in the +DIP treatments might be AISP which was used upon P-deficient environment.

It is expected that APase might overcome P deficiency together with amply supply of the substrate. The use of glycerophosphate and other DOP gave quite similar growth rates to that obtained with inorganic ones [5153]. In contrast to the above results, the lowest cell densities in the glycerophosphate treatments were detected, with their growth even not as good as that in the $\mathrm{P}$-depleted treatments with P-free condition. The APA in $+\mathrm{DOP}_{\alpha}$ and $+\mathrm{DOP}_{\beta}$ treatments were significantly lower than that in the P-depleted treatment. Obviously, APA was not regulated by substrate DOP, which was also observed in the culture of Microcystis aeruginosa [32]. Low activity in the +DOP treatments could be resulted from feedback inhibition of APA by the phosphate produced in the glycerophosphate hydrolysis [53]. For example, low levels of external phosphate were sufficient to induce repression of APA in Gelidium latifolium [54]. Despite the repression of APA in $+\mathrm{DOP}_{\alpha}$ and $+\mathrm{DOP}_{\beta}$ treatments, as well as the significantly lower exhibition of ELFp compared with the values in the P-depleted treatments, ELFp were much higher than that in +DIP treatments (round 18-to 26-fold), irrespective of the strains studied (Additional file 1: Fig. S4). Consistently, the Coccomyxa isolated from Lakes Plesne and Hromnice in Czechia increased in cell-specific phosphatase activity measured combining the ELF assay with image analysis at low $\mathrm{P}$ concentration and the cultures treated with DOP ( $\beta$-glycerol phosphate), which generated remarkably higher activity than those supplied with the same Pi concentrations [55]. Therefore, APase in A. flosaquae could perform its function of hydrolyzing organic $\mathrm{P}$, as illustrated by significant and positive relationship between the ELFp and $\mathrm{APA}_{>3.0 \mu \mathrm{m}}$ (Additional file 1: Fig. S2). Furthermore, the SRP concentrations in the $+\mathrm{DOP}_{\alpha}$ and $+\mathrm{DOP}_{\beta}$ treatments appeared increasing before day 15 with the expense of the DOP concentrations (Fig. 4b, c), which was an additional evidence that the DOP had been decomposed by the enzyme. On the other hand, it was noted that three strains of A. flos-aquae in $+\mathrm{DOP}_{\alpha}$ and $+\mathrm{DOP}_{\beta}$ treatments showed fluctuations in both PPBp (Fig. 8b, c) and number of PPB per cell (Fig. 9a-d) along the culture period. The PPB in the +DOP treatments might mainly be the ASP, which was rapidly utilized after approximate three days by microorganisms in waste-water [48]. Noticeably, no growth rate was determined and the photochemical efficiency in terms of $F v$ / $F m$ values was comparable during the whole experiment in the treatments of +DIP and +DOP. Shortly, the effective DOP mineralization and continuous processes of production and consumption of $\mathrm{PPB}$ in the $+\mathrm{DOP}$ treatments supported an active and sustainable growth but not reproduction for A. flos-aquae in +DOP treatments. Consistent to our observation, the growth rate of A. flos-aquae TR183 isolated from Baltic Sea in P-deplete treatment was a little higher than that in glycerol phosphate culture and it yielded lower biomass in glycerol phosphate culture when the Pi in the medium was not depleted than that in Pi-replete condition [12]. This suggested that $A$. flos-aquae is a species that grows better in high Pi pulse supply. The coordination of DOP mineralization and prompt utilization of PPB in A. flos-aquae might contribute to this maintaining growth, which was in accordance with the statement raised by Strojsova et al. [56] that the ability to decompose organic polymers and particles with extracellular phosphatases was beneficial for longer persistence of given population in a Piscarce circumstance.

\section{Conclusion}

Our findings provided evidence that $\mathrm{P}$ utilization strategies in A. flos-aquae, including producing APase, increase PPB formation and decrease cell P quota, played an important role in response to $\mathrm{P}$ stress. DOP was an important alternative $\mathrm{P}$ source for longer maintenance in filamentous cyanobacteria under Pi deficiency. Persistent and active reproduction could only be achieved in high pulse Pi supply, implying that an effective consequence can be expected for combating the bloom of A. flosaquae when controlling P supply.

\section{Supplementary information}

Supplementary information accompanies this paper at https://doi. org/10.1186/s12302-020-00328-3.

Additional file 1. Additional figures and table.

\section{Abbreviations}

P: Phosphorus; Pi: Inorganic P; PPB: Polyphosphate body; APase: Alkaline phosphatase; SRP: Soluble reactive P; DOP: Dissolved organic P; APA: Alkaline phosphatase activity; ELF: Enzyme-labeled fluorescence; Fv/Fm: Photosystem II quantum efficiency; A. flos-aquae 1249: Aphanizomenon flos-aquae FACHB 1249; A. flos-aquae 1171: Aphanizomenon flos-aquae FACHB 1171; A. flos-aquae 1260: Aphanizomenon flos-aquae FACHB 1260; ELFp: Percentages of cells with ELF labeling; PPBp: Percentages of PPB containing cells with PPB staining.

\section{Acknowledgements}

Not applicable.

\section{Authors' contributions}

YZ, CS, XCao, AS and TJ conceived and initiated the project. XCao, ID, AS, TJ, PF, AW and QD took field samples and chemical analysis. X. Cao and X. Chen designed the culture experiments. $X$. Chen and LW performed the experiment and analysis. X. Chen, YZ, X. Cao, and CS analyzed the data and composed the manuscript. All authors analyzed the results and edited the manuscript. All authors read and approved the final manuscript. 


\section{Funding}

This work was supported by grants from the National Key Research and Development Program of China (2016YFE0202100), Natural Science Foundation of China $(91951119,41573110,41273089)$, the State Key Laboratory of Freshwater Ecology and Biotechnology (2019FBZ01), Sino-Czechia cooperation financed by Chinese Academy of Sciences and Sino-Poland cooperation financed by Ministry of Science and Technology of the People's Republic of China

\section{Availability of data and materials}

The data sets supporting the conclusions of this article are included within the article and its Additional file.

\section{Ethics approval and consent to participate}

Not applicable.

\section{Consent for publication}

Not applicable.

\section{Competing interests}

The authors declare that they have no competing interests.

\begin{abstract}
Author details
${ }^{1}$ Key Laboratory of Algal Biology, State Key Laboratory of Freshwater Ecology and Biotechnology, Institute of Hydrobiology, Chinese Academy of Sciences, 7\# Donghu South Road, Wuhan 430072, China. ${ }^{2}$ University of Chinese Academy of Sciences, Beijing, China. ${ }^{3}$ Institute for Nanomaterials, Advanced Technologies and Innovation, Technical University of Liberec, Studentska 2, 46117 Liberec, Czechia. ${ }^{4}$ Department of Applied Ecology, Faculty of Biology and Environmental Protection, University of Lodz, Lodz, Poland.
\end{abstract}

Received: 28 December 2019 Accepted: 8 March 2020

Published online: 16 March 2020

\section{References}

1. Hadas O, Pinkas R, Delphine E, Vardi A, Kaplan A, Sukenik A (1999) Limnological and ecophysiological aspects of Aphanizomenon ovalisporum bloom in Lake Kinneret, Israel. J Plankton Res 21:1439-1453. https://doi. org/10.1093/plankt/21.8.1439

2. Kahru M, Leppanen JM, Rud O, Savchuk OP (2000) Cyanobacteria blooms in the Gulf of Finland triggered by saltwater inflow into the Baltic Sea. Mar Ecol Prog Ser 207:13-18. https://doi.org/10.3354/Meps207013

3. Kanoshina I, Lips U, Leppanen JM (2003) The influence of weather conditions (temperature and wind) on cyanobacterial bloom development in the Gulf of Finland (Baltic Sea). Harmful Algae 2:29-41. https://doi. org/10.1016/S1568-9883(02)00085-9

4. Liu YM, Chen W, Li DH, Shen YW, Li GB, Liu YD (2006) First report of aphantoxins in China-waterblooms of toxigenic Aphanizomenon flos-aquae in Lake Dianchi. Ecotox Environ Safe 65:84-92. https://doi.org/10.1016/j. ecoenv.2005.06.012

5. Janson S, Graneli E (2002) Phylogenetic analyses of nitrogen-fixing cyanobacteria from the Baltic Sea reveal sequence anomalies in the phycocyanin operon. Int J Syst Evol Micr 52:1397-1404. https://doi.org/10.1099/ ijs.0.02111-0

6. Walve J, Larsson U (2010) Seasonal changes in Baltic Sea seston stoichiometry: the influence of diazotrophic cyanobacteria. Mar Ecol Prog Ser 407:13-25. https://doi.org/10.3354/meps08551

7. Degerholm J, Gundersen K, Bergman B, Soderback E (2006) Phosphoruslimited growth dynamics in two Baltic Sea cyanobacteria, Nodularia sp. and Aphanizomenon sp. FEMS Microbiol Ecol 58:323-332. https://doi.org/ 10.1111/j.1574-6941.2006.00180.x

8. De Figueiredo DR, Goncalves AMM, Castro BB, Goncalves F, Pereira MJ, Correia A (2011) Differential inter- and intra-specific responses of Aphanizomenon strains to nutrient limitation and algal growth inhibition. J Plankton Res 33:1606-1616. https://doi.org/10.1093/plankt/fbr058

9. Garbisu C, Hall DO, Serra JL (1993) Removal of phosphate by foam-immobilized Phormidium laminosum in batch and continuous-flow bioreactors. J Chem Technol Biot 57:181-189. https://doi.org/10.1002/jctb.280570214
10. Janson S, Carpenter EJ, Bergman B (1994) Fine-structure and immunolocalization of proteins in Aphanizomenon sp. from the Baltic Sea. Eur J Phycol 29:203-211. https://doi.org/10.1080/09670269400650651

11. Strojsova A, Vrba J, Nedoma N, Komarkova J, Znachor P (2003) Seasonal study of extracellular phosphatase expression in the phytoplankton of a eutrophic reservoir. Eur J Phycol 38:295-306. https://doi. org/10.1080/09670260310001612628

12. Vahtera E, Laamanen M, Rintala JM (2007) Use of different phosphorus sources by the bloom-forming cyanobacteria Aphanizomenon flos-aquae and Nodularia spumigena. Aquat Microb Ecol 46:225-237. https://doi. org/10.3354/Ame046225

13. Vahtera E, Autio R, Kaartokallio H, Laamanen M (2010) Phosphate addition to phosphorus-deficient Baltic Sea plankton communities benefits nitrogen-fixing cyanobacteria. Aquat Microb Ecol 60:43-57. https://doi. org/10.3354/ame01408

14. Bar-Yosef Y, Sukenik A, Hadas O, Viner-Mozzini Y, Kaplan A (2010) Enslavement in the water body by toxic Aphanizomenon ovalisporum, inducing alkaline phosphatase in phytoplanktons. Curr Biol 20:1557-1561. https:// doi.org/10.1016/j.cub.2010.07.032

15. Murphy J, Riley JP (1962) A modified single solution method for determination of phosphate in natural waters. Anal Chim Acta 26:31-36

16. Wang SY, Xiao J, Wan LL, Zhou ZJ, Wang ZC, Song CL, Zhou YY, Cao XY (2018) Mutual dependence of nitrogen and phosphorus as key nutrient elements: one facilitates Dolichospermum flos-aquae to overcome the limitations of the other. Environ Sci Technol 52:5653-5661. https://doi. org/10.1021/acs.est.7b04992

17. Stanier RY, Deruelles J, Waterbury JB, Herdman M, Rippka R (1979) Generic assignments, strain histories and properties of pure cultures of cyanobacteria. Microbiology 111:1-61. https://doi.org/10.1099/00221287-111-1-1

18. Bowe $G$ (2002) An overview of counting methods of algae. In: Ziglio G, van der Beken A (eds) Water quality measurements series: detection methods for algae, protozoa and Helminths in fresh and drinking water (Palumbo F. Wiley, England, pp 71-82

19. Wu ZX, Shi JQ, Li RH (2009) Comparative studies on photosynthesis and phosphate metabolism of cylindrospermopsis raciborskii with Microcystis aeruginosa and Aphanizomenon flos-aquae. Harmful Algae 8(6):910-915. https://doi.org/10.1016/j.hal.2009.05.002

20. Guo H, Yao JT, Sun ZM, Duan DL (2015) Effect of temperature, irradiance on the growth of the green alga Caulerpa lentillifera (Bryopsidophyceae, Chlorophyta). J Appl Phycol 27:879-885. https://doi.org/10.1007/s1081 1-014-0358-7

21. Ting CS, Owens TG (1992) Limitations of the pulse-modulated technique for measuring the fluorescence characteristics of algae. Plant Physiol 100:367-373. https://doi.org/10.1104/Pp.100.1.367

22. Beattie DM, Golterman HL, Vijverberg J (1978) Introduction to limnology of Friesian Lakes. Hydrobiologia 58:49-64. https://doi.org/10.1007/Bf000 18895

23. Hoppe HG (1993) Use of fluorogenic model substrates for extracellular enzyme activity (EEA) measurement of bacteria. In: Kemp PF, Cole JJ, Sherr BF, Sherr EB, Cole JJ (eds) Handbook of methods in aquatic microbial ecology. Lewis Publishers, Boca Raton, pp 423-431. https://doi. org/10.1080/09670260310001612628

24. Wan LL, Chen $X Y$, Deng $Q H$, Yang L, Li XW, Zhang JY, Song CL, Zhou YY, Cao XY (2019) Phosphorus strategy in bloom-forming cyanobacteria (Dolichospermum and Microcystis) and its role in their succession. Harmful Algae 84:46-55. https://doi.org/10.1016/j.hal.2019.02.007

25. Allan RA, Miller JJ (1980) Influence of S-adenosylmethionine on DAPIinduced fluorescence of polyphosphate in the yeast vacuole. Can J Microbiol 26:912-920. https://doi.org/10.1139/M80-158

26. Tijssen JPF, Beekes HW, Vansteveninck J (1982) Localization of polyphos phates in Saccharomyces-Fragilis, as revealed by 4',6-Diamidino-2-Phenylindole fluorescence. Biochim Biophys Acta 721:394-398. https://doi. org/10.1016/0167-4889(82)90094-5

27. Jansson M, Olsson H, Pettersson K (1988) Phosphatases-origin, characteristics and function in lakes. Hydrobiologia 170:157-175. https://doi. org/10.1007/Bf00024903

28. Istvanovics V, Pettersson K, Pierson D, Bell R (1992) Evaluation of phosphorus deficiency indicators for summer phytoplankton in Lake Erken. Limnol Oceanogr 37:890-900. https://doi.org/10.4319/lo.1992.37.4.0890 
29. Sohm JA, Capone DG (2006) Phosphorus dynamics of the tropical and subtropical North Atlantic: Trichodesmium spp. versus bulk plankton. Mar Ecol Prog Ser 317:21-28. https://doi.org/10.3354/Meps317021

30. Cao XY, Song CL, Zhou YY (2010) Limitations of using extracellular alkaline phosphatase activities as a general indicator for describing P deficiency of phytoplankton in Chinese shallow lakes. J Appl Phycol 22:33-41. https ://doi.org/10.1007/s10811-009-9422-0

31. Duhamel S, Dyhrman ST, Karl DM (2010) Alkaline phosphatase activity and regulation in the North Pacific Subtropical Gyre. Limnol Oceanogr 55:1414-1425. https://doi.org/10.4319/lo.2010.55.3.1414

32. Harke MJ, Berry DL, Ammerman JW, Gobler CJ (2012) Molecular response of the bloom-forming cyanobacterium, Microcystis aeruginosa, to phosphorus limitation. Microb Ecol 63:188-198. https://doi.org/10.1007/s0024 8-011-9894-8

33. Jamet D, Amblard C, Devaux J (2001) Size-fractionated alkaline phosphatase activity in the hypereutrophic Villerest reservoir (Roanne, France). Water Environ Res 73:132-141. https://doi.org/10.2175/106143001×13878 7

34. Rengefors K, Ruttenberg KC, Haupert CL, Taylor C, Howes BL, Anderson DM (2003) Experimental investigation of taxon-specific response of alkaline phosphatase activity in natural freshwater phytoplankton. Limnol Oceanogr 48:1167-1175. https://doi.org/10.4319/lo.2003.48.3.1167

35. Meseck SL, Alix JH, Wikfors GH, Ward JE (2009) Differences in the soluble, residual phosphate concentrations at which coastal phytoplankton species up-regulate alkaline-phosphatase expression, as measured by flow-cytometric detection of ELF-97A (R) Fluorescence. Estuar Coast 32:1195-1204. https://doi.org/10.1007/s12237-009-9211-7

36. Jauzein C, Labry C, Youenou A, Quere J, Delmas D, Collos Y (2010) Growth and phosphorus uptake by the toxic dinoflagellate Alexandrium Catenella (Dinophyceae) in response to phosphate limitation. J Phycol 46:926-936. https://doi.org/10.1111/j.1529-8817.2010.00878.x

37. Oh SJ, Yamamoto T, Kataoka Y, Matsuda O, Matsuyama Y, Kotani Y (2002) Utilization of dissolved organic phosphorus by the two toxic dinoflagellates, Alexandrium tamarense and Gymnodinium catenatum (Dinophyceae). Fisheries Sci 68:416-424. https://doi.org/10.104 6/j.1444-2906.2002.00440.x

38. Lehman JT, Doubek JP, Jackson EW (2013) Effect of reducing allochthonous $P$ load on biomass and alkaline phosphatase activity of phytoplankton in an urbanized watershed, Michigan. Lake Reserv Manage. 29(2):116-125. https://doi.org/10.1080/10402381.2013.800173

39. Prentice MJ, Hamilton DP, Willis A, O'Brien KR, Burford MA (2019) Quantifying the role of organic phosphorus mineralisation on phytoplankton communities in a warm-monomictic lake. Inland Waters 9:10-24. https:// doi.org/10.1080/20442041.2018.1538717

40. Wu G, Zhou X (2005) Characterization of phosphorus-releasing bacteria in a small eutrophic shallow lake. Eastern China. Water Res. 39:4623-4632. https://doi.org/10.1016/j.watres.2005.08.036

41. Cao XY, Zhou YY, Wang ZC, Song CL (2016) The contribution of attached bacteria to microcystis bloom: evidence from field investigation and microcosm experiment. Geomicrobiol J 33:607-617. https://doi. org/10.1080/01490451.2015.1074319

42. Yang L, Liu YQ, Cao XY, Zhou ZJ, Wang SY, Xiao J, Song CL, Zhou YY (2017) Community composition specificity and potential role of phosphorus solubilizing bacteria attached on the different bloom-forming cyanobacteria. Microbiol Res 205:56-60. https://doi.org/10.1016/j.micres.2017.08.013
43. Lean DRS, Nalewajko C (1976) Phosphate exchange and organic phosphorus excretion by freshwater algae. J Fish Res Board Can 33(6):13121323. https://doi.org/10.1139/F76-169

44. Hagemann M, Moke F, Springer A, Westermann L, Frank M, Wasmund N Bauwe H (2019) Cyanobacterium Nodularia spumigena strain CCY9414 accumulates polyphosphate under long-term P-limiting conditions. Aquat Microb Ecol 82:265-274. https://doi.org/10.3354/ame01896

45. Martin P, Dyhrman ST, Lomas MW, Poulton NJ, Van Mooy BAS (2014) Accumulation and enhanced cycling of polyphosphate by Sargasso Sea plankton in response to low phosphorus. P Natl Acad Sci USA 111:80898094. https://doi.org/10.1073/pnas.1321719111

46. Frischkorn KR, Haley ST, Dyhrman ST (2019) Transcriptional and proteomic choreography under phosphorus deficiency and re-supply in the N-2 fixing cyanobacterium Trichodesmium erythraeum. Front Microbiol. https ://doi.org/10.3389/Fmicb.2019.00330

47. Miyachi S, Kanai R, Aoki S, Mihara S (1964) Metabolic roles of inorganic polyphosphates in Chlorella cells. Biochim Biophys Acta 93(3):625-634. https://doi.org/10.1016/0304-4165(64)90345-9

48. Powell N, Shilton A, Chisti Y, Pratt S (2009) Towards a luxury uptake process via microalgae-defining the polyphosphate dynamics. Water Res 43:4207-4213. https://doi.org/10.1016/j.watres.2009.06.011

49. Jansson M (1988) Phosphate-uptake and utilization by bacteria and algae. Hydrobiologia 170:177-189. https://doi.org/10.1007/Bf00024904

50. John EH, Flynn KJ (2000) Modelling phosphate transport and assimilation in microalgae; how much complexity is warranted? Ecol Model 125:145-157. https://doi.org/10.1016/S0304-3800(99)00178-7

51. Berman T, Chava S, Kaplan B, Wynne D (1991) Dissolved organic substrates as phosphorus and nitrogen-sources for axenic batch cultures of fresh-water Green-algae. Phycologia 30:339-345. https://doi.org/10.2216/ i0031-8884-30-4-339.1

52. Van Boekel WHM (1991) Ability of Phaecystis sp. to grow on organic phosphates: direct measurements and prediction with the use of an inhibition constant. J Plankton Res 13:959-970

53. Stihl A, Sommer U, Post AF (2001) Alkaline phosphatase activities among populations of the colony-forming diazotrophic cyanobacterium Trichodesmium spp. (cyanobacteria) in the Red Sea. J Phycol 37:310-317. https://doi.org/10.1046/j.1529-8817.2001.037002310.x

54. Hernandez I, Fernandez JA, Niell FX (1995) A Comparative-study of alkaline-phosphatase activity in 2 species of Gelidium (Gelidiales, Rhodophyta). Eur J Phycol 30:69-77. https://doi.org/10.1080/096702695006508 11

55. Vrba J, Macholdova M, Nedbalova L, Nedoma J, Sorf M (2018) An experimental insight into extracellular phosphatases-differential induction of cell-specific activity in green algae cultured under various phosphorus conditions. Front Microbiol 9:271. https://doi.org/10.3389/fmicb 2018.00271

56. Strojsova A, Nedoma J, Strojsova M, Cao XY, Vrba J (2008) The role of cell-surface-bound phosphatases in species competition within natural phytoplankton assemblage: an in situ experiment. J Limnol 67:128-138. https://doi.org/10.4081/jlimnol.2008.128

\section{Publisher's Note}

Springer Nature remains neutral with regard to jurisdictional claims in published maps and institutional affiliations. 